\title{
Tiempo y memoria
}

T ENÍAMOS la impresión de que no ocurría nada desde hacía algún tiempo. Vivíamos en una especie de árido vacío en el que, no obstante la apatía, erraba la espera de algo... imposible de precisar.

De pronto, el tiempo, el otro tiempo, el tiempo anterior al 19 de septiembre fue profunda y brutalmente trastocado, roto, fracturado por un cataclismo: la destrucción sísmica de la vida en común - no siempre comunitaria.

Ocurrió, pues, algo... que nadie esperaba. Como siempre, frente al orden de la realidad se produjo el acontecimiento inesperado; el vacío fue colmado por un vacío mayor y la aridez cedió su lugar a la desolación. La nada devoró a la nada. Se produjo la fractura del tiempo.

¿Pueden, ahora, las cosas ser como antes?

Hay aquéllos para quienes, por un lado, nada será nunca como antes.

Hay aquéllos para quienes, por otro lado -que a fin de cuentas es el mismo lado-, no hay nada que hacer sino olvidar y hacer como si no hubiese pasado nada.

En el primer caso se piensa, tal vez, en el apocalipsis.

En el segundo caso se convoca a una pérdida total de la memoria.

En ambos casos se trata pura y simplemente de una necedad.

Hay muchas cosas que siguen siendo como antes: la parte de la ciudad que no fue directamente afectada por el terremoto vive inmersa en el ritmo de antes: tiene agua, electricidad, gas, teléfono; tiene supermercados repletos de mercancías, gasoli- 
neras en servicio; restaurantes en donde se sirve a la clientela habitual, escuelas donde se imparten cursos... No obstante los escombros, la vida transcurre.

Sin embargo, esto sucede en la ciudad de al lado, en la ciudad que, pese a todo, no vivió una agonía. Junto a ella está la otra ciudad, la ciudad en donde las cosas ya no son como antes y para la que el olvido no tiene ninguna razón de ser, pues es la ciudad en ruinas, la ciudad abismada en sus fracturas y en sus grietas, la ciudad que pereció bajo los escombros, la que muere y llora a sus muertos y el olvido, por lo tanto, no es para ella.

Las dos ciudades, la que muere y la que asiste a sus funerales vivieron, o presenciaron, la destrucción de la vida en común. Para las dos cambiaron el orden del día y las horas de la noche. ¿O acaso se puede dormir con el fantasma de un Richter paseándose por el dédalo de nuestros sueños? ¿Se puede llamar vida cotidiana al incesante ulular de las sirenas? ¿Son costumbre los soldados apostados en las fronteras de los escombros y las imágenes de una ciudad bombardeada? ¿Dónde estamos? ¿Qué fecha es hoy? ¿En dónde empiezan la vida y la muerte? ¿Es hora de comer o de dormir?

Nuestro tiempo es hoy otro tiempo. El orden de la realidad se desplazó... no sabemos cuántas pulgadas, y la reflexión es hoy más que nunca una necesidad, pues para no perder la memoria hay que pensar, y esto hay que hacerlo sin catastrofismos. De lo contrario nuevamente tendríamos ante nosotros el vacío y esta vez, sí, verdaderamente estéril.

Una vez más nos espera algo. Y este algo se puede, tal vez, precisar sin la apatía o el descreimiento de antes. La movilización, la solidaridad, el emprendimiento de la población civil son quizá el anuncio de ese algo, aunque no podemos dejar de lado que cuando se altera el orden de la realidad se produce una reacción biológica de la especie.

EL DIRECTOK 